\title{
Implementasi Metode Taboo Code Untuk Kompresi File Video
}

\author{
Saiful Simanjuntak \\ Program Studi Teknik Informatika, Fakultas Ilmu Komputer dan Teknologi Informasi, Universitas Budi Darma, \\ Jalan. Sisingamangaraja No. 338, Medan, Sumatera Utara, Indonesia \\ Email : saifulsimanjuntak11@gmail.com
}

\begin{abstract}
Abstrak-Video adalah teknologi untuk menangkap, merekam, memproses, dan menataulang gambar bergerak yang biasanya menggunakan sinyal elektronik, atau media digital. Misalnya, file video yang ukurannya besar mengakibatkan proses pengiriman semakin lama, serta menggunakan ruang memori yang besar dalam penyimpanannya. Permasalahan yang lahir karena besarnya ukuran file antara lain adalah borosnya media penyimpanan yang digunakan, serta memakan waktu lebih banyak dalam hal pertukaran data, transfer data melalui jaringan internet menjadi masalah besar di Indonesia karena kecepatan download dan upload yang sangat rendah. Untuk mengatasi masalah tersebut maka diperlukan teknik kompresi data. Konsep kompresi lahir sebagai solusi nyata dari permasalahan mengenai besarnya ruang yang dibutuhkan untuk menyimpan berbagaimacam file digital, tidak terkecuali dengan file video. Teknik kompresi merupakan teknik yang memadatkan isi file sehingga ukurannya menjadi lebih kecil dengan tetap menjaga kualitas represntasi dari file tersebut.
\end{abstract}

Kata Kunci: Kompresi; File Video; Algoritma Taboo Code

Abstrac-Video is a technology for capturing, recording, processing, and rearranging images usually using electronic signals, or digital media. For example, a video file that is large in size causes the sending process to take longer, and uses a large amount of memory space in its storage. Problems that arise due to the large file size include the wasteful storage media used, as well as more time in terms of data exchange, data transfer via the internet is a big problem in Indonesia because download and upload speeds are very low. To overcome this problem, data compression techniques are needed. The concept of compression was born as a real solution to the problem of the amount of space needed to store various digital files, including video files. Compression technique is a technique that compresses files so that their size becomes smaller while maintaining the quality of the representation of the filet.

Keywords: Compression; Video Files; Taboo Code Algorithm

\section{PENDAHULUAN}

Perkembangan teknologi yang begitu cepat seperti sekarang ini sangat bermanfaat guna bertukar informasi secara global baik itu dalam bentuk teks, gambar, audio ataupun video. Sehingga secara tidak langsung menimbulkan masalah yaitu membuat kebutuhan akan penyimpanan semakin meningkat. Dan bila mengirimkan data melalui media transmisi, maka akan memerlukan waktu yang semakin lama untuk proses pengiriman data tersebut. Untuk itu diperlukan suatu teknik yang dapat mereduksi besarnya ukuran suatu file yang disebut kompresi data. Kompresi data adalah proses yang dapat mengubah sebuah aliran data masukan (sumber atau data asli) ke dalam aliran data yang lain (keluaran atau data yang dimampatkan) yang memiliki ukuran lebih kecil[1]. Kompresi data menjadi sangat penting karena memperkecil kebutuhan penyimpanan data, dan mempercepat pengiriman data. Pada penelitian sebelumnya mengenai kompresi file video yang berjudul "Kompresi File Video MP4 Dengan Menggunakan Metode Discrete Cosine Transform" oleh Rizky Syahputra pada tahun 2016. Pada penelitian tersebut memiliki kekurangan yaitu metode discrete cosine transform tidak tahan terhadap perubahan suatu objek dikarenakan pesan mudah dihapus karena lokasi penyisipan data dan pembuatan data dengan metode DCT diketahui [2]. Penelitian lainnya yang berjudul "Perancangan Dan Implementasi Algoritma Arithmetic Coding Untuk Aplikasi Kompresi Data Video dan Audio" oleh Hengki Tomando Sihotang tahun 2018. Pada penelitian tersebut dinyatakan bahwa ukuran file sebelum kompresi sama dengan ukuran file sesudah didekompresi yang berarti bahwa tidak ada data yang hilang selama proses kompresi dan waktu yang diperlukan untuk kompresi file MP4. Algoritma Arithmetic Coding tidak optimal dalam melakukan kompresi audio dan video dapat dilihat pada rasio kompresi yang rendah dan grafik yang tidak stabil[3]. Pada penelitian ini algoritma yang digunakan adalah algoritma Taboo Code. Algoritma Taboo Code memiliki pendekatan terhadap panjangnya suatu variable. Penggagas Algoritma Taboo Code adalah Steven Pigeon. Prinsip dari Algoritma taboo code untuk memilih bilangan positif n dan membalikkan pola $\mathrm{n}$ untuk mengindikasikan akhir dari kode tersebut[3].

\section{METODOLOGI PENELITIAN}

\subsection{Kompresi}

Kompresi merupakan proses untuk menghilangkan berbagai kerumitan yang tidak penting (redundansi) dari suatu informasi dengan cara memadatkan isi file sehingga ukurannya menjadi lebih kecil dengan memaksimalkan kesederhanaannya dan tetap menjaga kualitas penggambaran dari informasi tersebut[4].

\subsection{Rasio Kompresi (Compression Ratio)}

Compression Ratio adalah presentasi besar data yang telah dikompresi yang didapat dari hasil perbandingan antara ukuran data setelah dikompresi dengan ukuran sebelum dikompresi[5]. 


\subsection{Video MP4}

MP4 adalah salah satu format video yang mungkin sering dijumpai di internet. MP4 merupakan alternatif format video selain beberapa format video Digital seperti AVI, MKV, 3GP, RMVB dimana masing-masing memiliki sifat dan kualitas yang berlainan.Format MP4 biasanya digunakan untuk video dengan kualitas tinggi yang tidak semua PC mampu memutarnya dengan baik. Sebuah file video digital dalam format MP4 memiliki beberapa bagian, yaitu : a. Video b. Audio c. Subtitle, Semua bagian ini terpisah, namun menjadi satu bagian didalam format MP4. Bagianbagian ini nantinya akan digabungkan menggunakan sebuah codec MP4 sehingga video Digital dalam format MP4 ini dapat dibaca dan dijalankan menggunakan perangkat lunak multimedia player.[6]

\subsection{Algoritma taboo Code}

Algoritma Taboo memiliki pendekatan terhadapat panjangnya suatu variable. Penggagas Algoritma Taboo adalah Steven Pigeon. Prinsip dari Algoritma Taboo yaitu untuk memilih bilangan positif $\mathrm{n}$ dan membalikkan pola $\mathrm{n}$ untuk mengindikasikan akhir dari kode tersebut[7].

Terdapat dua tipe yang yang ada dalam Algoritma Taboo diantaranya:

1. Tipe pertama dari Algoritma Taboo yaitu block-based dan memiliki panjang berupa kelipatan dari n. Block based Algoritma Taboo dari integer adalah string dari n- bit blocks, dimana nilai n dipilih oleh user dan blok terakhir memiliki sedikit pola taboo yang tidak dapat mucul pada blok lainnya. n-bit blok memilik nilai $2^{\text {n }}$, jika salah satu nilai dicadangkan, masing-masing sisa kode blok dapat memiliki salah satu yang ada pada pola bit $2^{\mathrm{n}}-1$.

2. Tipe kedua dari Algoritma Taboo yaitu panjang total kode ini tidak terbatas pada kelipatann. Tipe ini dikatakan unconstrained dan ditunjukkan bahwa tipe ini memiliki relasi terhadap nomor fibonaci ke-n.

Rumus dari Algoritma Taboo codes yaitu:

$$
\begin{array}{ll}
\boldsymbol{g}_{n}(\boldsymbol{k})= & \sum_{i}^{k}\left(2^{n}-\mathbf{1}\right)^{i}=\frac{\left[\left(2^{n}-1\right)^{k}-1\right]\left(2^{n}-1\right)}{2^{n}-2} \\
\boldsymbol{g}_{n}(\boldsymbol{k}) & : \text { jumlah total kode dalam rentang k } \\
\boldsymbol{n} & : \text { jumlah blok bit }
\end{array}
$$

Tabel 1. Pola Taboo Codes

\begin{tabular}{rrrrrrrc}
\hline $\mathbf{m}$ & Code & $\mathbf{m}$ & Code & $\mathbf{M}$ & Code & $\mathbf{m}$ & Code \\
\hline $\mathbf{0}$ & 0100 & $\mathbf{4}$ & 011000 & $\mathbf{8}$ & 101100 & $\mathbf{1 2}$ & 01010100 \\
$\mathbf{1}$ & 1000 & $\mathbf{5}$ & 011100 & $\mathbf{9}$ & 110100 & $\mathbf{1 3}$ & 01011000 \\
$\mathbf{2}$ & 1100 & $\mathbf{6}$ & 100100 & $\mathbf{1 0}$ & 111000 & $\mathbf{1 4}$ & 01011100 \\
$\mathbf{3}$ & 010100 & $\mathbf{7}$ & 101000 & $\mathbf{1 1}$ & 111100 & $\mathbf{\ldots}$ & \\
\hline
\end{tabular}

\section{HASIL DAN PEMBAHASAN}

Salah satu permasalahan yang hadir di era milenial ini adalah semua kebutuhan yang dilakukan banyak orang sangat bergantung pada teknologi dan dunia digital, dunia teknologi saat ini sudah sangat modern sehingga mengakibatkan file berupa text juga membutuhkan ruang penyimpanan yang besar sehingga membuat pemborosan di ruang penyimpanan, dan koneksi internet di Indonesia juga sangat rendah sehingga dibutuhkan proses transfer data secara cepat baik secara online maupun offline. Pada penilitian ini akan dilakukakan analisa dan perancangan sistem pengkompresian file video menggunakan algoritma Taboo Codes.

Algoritma Taboo Codes merupakan algoritma kompresi yang bersifat lossless, algoritma Taboo Codes mengkompresi file dengan frekuensi karakter pada objek yang akan dilakukan kompresi. Algoritma Taboo Codes bekerja dengan cara mengurutkan karakter yang sering muncul dan menggantikan bilangan biner dari setiap karakter menjadi nilai kebenaran berdasarkan tabel kebenaran algoritma Taboo Codes.

Permasalahan yang diangkat dari penelitian ini adalah untuk mendapatkan algoritma kompresi yang lebih baik yang akan digunakan untuk memperkecil. ukuran file video berformat *MP4 dengan menggunakan algoritma Taboo Codes. Pada penelitian ini prosedur kerjanya adalah dengan cara mengkompresi file video dan file video yang sudah dikompresi kemudian didekompresi lagi untuk mengembalikan file video ke format semula.

Adapun proses mengenai sistem dan cara kerja kompresi file video pada penelitian ini. Pada gambar dibawah dijelaksan contoh file video dikompresi menggunakan algoritma Taboo Codes dan menghasilkan output hasil kompresi berupa karakter/simbol-simbol unik, kemudian hasil dari kompresi file video yang berupa simbol unik tersebut selanjutnya dikompresi kembali menggunakan algoritma Taboo Codes untuk mengembalikan file asli berupa karakter tulisan. 


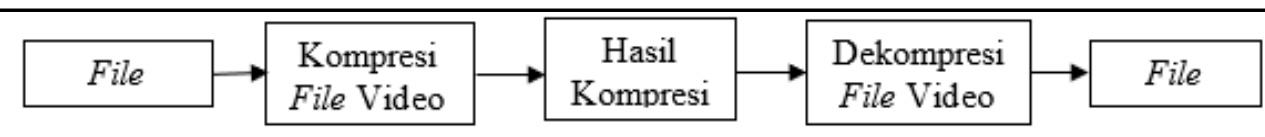

\section{Gambar 1. General Architecture System}

Penelitian ini membahasa 2 proses utama yaitu proses kompresi dan proses dekompresi, dalam penelitian ini penulis akan mengkompresi file video berformat *.doc menggunakan algoritma Taboo Codes, algoritma ini merupakan algoritma yang bersifat lossless sehingga file yang dikompresi tidak hilang banyak dan ketika didekompresi file akan kembali kepada ukuran semula sehingga tidak mempengaruhi isi file yang dikompresi dan tidak menghilangkan video.

Algoritma Taboo Codes memiliki pendekatan terhadapat panjangnya suatu variabel. Penggagas Algoritma Taboo Codes adalah Steven Pigeon. Prinsip dari Algoritma Taboo Codes yaitu untuk memilih bilangan positif $\mathrm{n}$ dan membalikkan pola $\mathrm{n}$ untukmengindikasikan akhir dari kode tersebut.

Terdapat dua tipe yang ada dalam Algoritma Taboo Codes diantaranya:

1. Tipe pertama dari Algoritma Taboo Codes yaitu block-based dan memiliki Panjang berupa kelipatan dari n.

Block based Algoritma Taboo Codes dari integer adalah string dari n- bit blocks, dimana nilai n dipilih oleh user dan blok terakhir memiliki sedikit pola taboo yang tidak dapat mucul pada blok lainnya. n-bit blok memilik nilai $2^{n}$, jika salah satu nilai dicadangkan, masing-masing sisa kode blok dapat memiliki salah satu yang ada pada pola bit $2^{n}-1$.

2. Tipe kedua dari Algoritma Taboo Codes yaitu panjang total kode ini tidak terbatas pada kelipatan. Tipe ini dikatakan unconstrained dan ditunjukkan bahwa tipe ini memiliki relasi terhadap nomor fibonaci ke-n.

\subsection{Prose Kompresi}

Sebelum file dikompresi, terlebih dahulu dilakukan pembacaan biner yang terdapat pada file video untuk mendapatkan data berupa data biner. Membaca biner yang terdapat pada file video menggunakan aplikasi Binery Viewer untuk mencari nilai biner pada file video. Tabel 2 adalah contoh file video yang akan dikompresi dan didekompresi.

Tabel 2. Sampel file video yang akan di kompresi

\begin{tabular}{ll}
\hline Nama File & Video Kebugaran Jasmani \\
Size & 150,8 MB \\
Type & MP4 \\
Durasi & $1: 30: 8$ Menit \\
\hline
\end{tabular}

Berdasarkan table 2 terdapat nilai biner viewer, adapun nilai hexadecimal dari contoh file video pada sampel E:/ Video Kebugaran Jasmani tersebut adalah : 


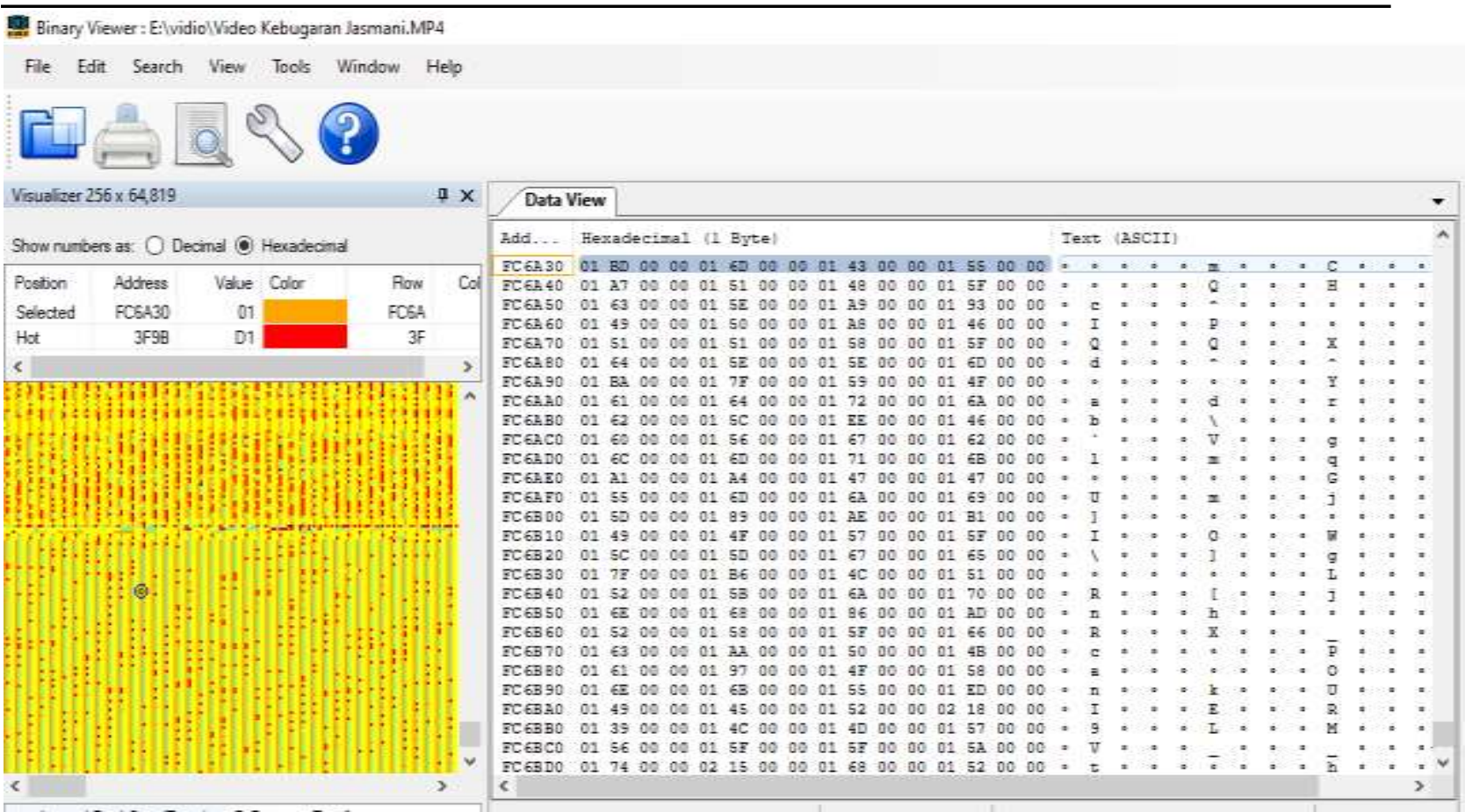

Gambar 2. Kode Hexadecimal file video dari hasil Binary Viewer

Tabel 3. String karakter yang belum dikompresi

\begin{tabular}{cccccc}
\hline M & Karakter & Frekuensi & ASCII (binary) & Bit & Frek $\times$ Bit \\
\hline 1 & 01 & 4 & 00000001 & 8 & 32 \\
2 & BD & 1 & 10111101 & 8 & 8 \\
3 & 00 & 4 & 00000000 & 8 & 32 \\
4 & $6 \mathrm{D}$ & 1 & 01101101 & 8 & 8 \\
5 & 43 & 1 & 01100011 & 8 & 8 \\
6 & 55 & 1 & 01010101 & 8 & 8 \\
\hline \multicolumn{5}{c}{ Total Bit } \\
\hline
\end{tabular}

Berdasarkan tabel 3, satu karakter bernilai delapan bit bilangan biner sehingga 12 karakter pada string mempunyai nilai biner sebanyak 96 bit. Algoritama Taboo Codes bekerja dengan memulai sorting jumlah frekuensi kemunculan setiap karakter yang akan dikompresi. Adapun string bit sebelum dikompresi adalah sebagai berikut: 000000011011110100000000011011010110001101010101

Setelah menentukan kemunculan setiap karakter dan mencari nilai bilangan biner dari setiap karakter, langkah selanjutnya adalah mengurutkan setiap karakter berdasarkan frekuensi kemunculan yang paling banyak pada setiap karakter. Setelah diurutkan berdasarkan frekuensi terbanyak, bilangan biner sebelum dikompresi pada setiap karakter diganti dengan kode kebeneran dari algoritma taboo codes yang diurutkan berdasarkan frekuensi kemunculan.

Tabel 4. Data Setelah Dikompresi Menggunakan Algoritma Taboo Codes

\begin{tabular}{cccccc}
\hline $\mathrm{N}$ & Char & Biner & Bit & Frek & Bit $\times$ Frek \\
\hline 1 & 01 & 0100 & 4 & 4 & 16 \\
2 & 00 & 1000 & 4 & 4 & 16 \\
3 & BD & 1100 & 4 & 1 & 4 \\
4 & $6 \mathrm{D}$ & 010100 & 6 & 1 & 6 \\
5 & 43 & 011000 & 6 & 1 & 6 \\
6 & 55 & 011100 & 6 & 1 & 6 \\
\hline \multicolumn{7}{c}{ Total Bit }
\end{tabular}

Setelah kode berhasil di encode berdasarkan kode kebenaran agloritma Taboo Codes, tahap selanjutnya adalah menyusun kembali kode-kode yang telah dihasilkan dari proses kompresi sesuai dengan posisi karakter pada string seperti pada tabel 4.

Tabel 5. String bit hasil kompresi dengan algoritma Taboo Codes 


\begin{tabular}{ccccc}
\hline 01 & BD & 00 & 01 & $6 \mathrm{D}$ \\
0100 & 1100 & 1000 & 0100 & 010100 \\
01 & 43 & 00 & 01 & 55 \\
1000 & 011000 & 1000 & 0100 & 011100 \\
\hline
\end{tabular}

Setelah setiap karakter disusun kembali menggunakan kode kebenaran algoritma taboo codes, tahap selanjutnya menyusun kembali hasil kompresi setiap karakter, sehingga diperoleh string bit sebagai berikut:

0100110010000100010100100001100010000100011100 .

Dalam hal penyimpanan data digunakan aturan 8 bit, sehingga untuk menyesuaikan data dengan aturan penyimpanan string bit sebanyak kekurangan dari kelipatan 8 . Setelah itu, untuk mengetahuii banyaknya padding dan flagging yang akan ditambahkan pada string bit kompresi, maka total dari keseluruhan kompresi string bit akan dibagi 8. Jika sisa bagi total seluruh string bit terhadap 8 adalah 0 maka akan ditambahkan string bit 00000001, sedangkan jika sisa bagi panjang string bit terhadap 8 tidak habis dibagi, maka akan ditambahkan padding dan flagging.

Tabel 6. Penambahan padding dan flagging

\begin{tabular}{cc}
\hline Padding & Flagging \\
\hline $7-n+" 1 "$ & $9-n$ \\
$7-6+" 1 "=01$ & $9-6=3$ \\
& 00000011 \\
\hline
\end{tabular}

Sehingga diperoleh string bit sebagai berikut: 010011001000010001010010000110001000010001110001 00000011. Dimana total dari keseluruhan bit yang telah ditambahkan padding dan flagging, panjang string bit awal adalah 54 setelah ditambahkan padding dan flagging panjang total keseluruha string bit menjadi 56 bit. Selanjutnya total seluruh string bit akan dibagi menjadi 8 bit dalam satu kelompok string bit, dan string bit yang sudah dikelompokkan akan diubah ke dalam bilangan desimal, bilangan desimal yang diperoleh dari bilangan kelompok biner selanjutnya akan diubah menjadi berbagai karakter unik yang terdapat pada tabel ASCII.

Tabel 7. Pengelompokan Bit

\begin{tabular}{ccc}
\hline No & String bit hasil kompresi & Bilangan Desimal \\
\hline 1 & 01001100 & 76 \\
2 & 10000100 & 132 \\
3 & 01010010 & 82 \\
4 & 00011000 & 24 \\
5 & 10000100 & 130 \\
6 & 01110001 & 113 \\
7 & 00000011 & 3 \\
\hline
\end{tabular}

Berdasarkan hasil kompresi file video diatas menggunakan algoritma Taboo Codes, maka didapatkan hasil kompresi string bit yang lebih sedikit yaitu sebanyak 56 string bit dari string bit awal sebanyak 96 string bit, sebagai berikut :

01001100100001000101001000011000100001000111000100000011.

\subsection{Parameter Analisis Kompresi}

Dari hasil kompresi diatas setiap kelompok string bit menghasilkan sebuah karakter unik, karakter unik tersebut akan disimpan kedalam notepad dengan ekstensi *.MP4. Dalam menganalisis algoritma kompresi parameter yang akan dipakai penulis sebagai tolak ukur untuk menentukan kinerja algoritma Taboo Codes adalah Compression Ratio dan Space Saving.

1. Compression Ratio

$$
\begin{aligned}
& C R=\frac{\text { ukuran data sesudah dikompresi }}{\text { ukuran data sebelum dikompresi }} \times 100 \% \\
& C R=\frac{56 \text { bit }}{96 \text { bit }} \times 100 \% \\
& C R=58,33 \%
\end{aligned}
$$

2. Space Saving

$$
\begin{aligned}
& S S=1-\frac{\text { ukuran file kompresi }}{\text { ukuran file asli }} \times 100 \% \\
& S S=1-\frac{56}{96} \times 100 \%
\end{aligned}
$$




$$
\begin{aligned}
& S S=(1-0.8533) \times 100 \% \\
& S S=0.1467 \times 100 \% \\
& S S=0.1467 \%
\end{aligned}
$$

\subsection{Proses Dekompresi}

Setelah file berhasil dikompresi maka akan menghasilkan file baru yang berisi informasi serta string bit dari hasil proses kompresi. Hasil kompresi dengan mengembalikan binary menjadi string bit semula dengan menghilangkan biner padding dan flagging. Untuk mengembalikan binary menjadi string bit semula dapat dilakukan melalui langkah berikut ini. Lakukan pembacaan pada 8 bit terakhir, hasil pembacaan berupa bilangan desimal. Nyatakan hasil pembacaan dengan $\mathrm{n}$, hilangkan bit pada bagian akhir sebanyak $7+n$, setelah dilakukan perhitungan pembacaan bit akhir, nilai biner yang dihilangkan sebanyak 8 bit pada akhir $n=6$, hilangkan $7+n$ atau $7+3=$ 10. Penjelasan diatas menunjukkan bahwa bit akhir harus dihilangkan. Hasil pengembalian binary menjadi string

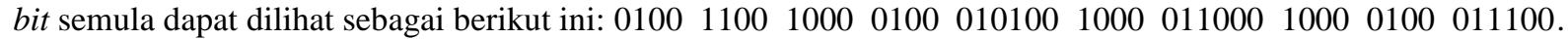

Setelah proses penghilangan padding dan flagging, langkah selanjutnya semua bilangan biner hasil kompresi akan diubah langsung ke bilangan biner sebelum didekompresi, pembacaan string bit dilakukandari indeks terkecil sampai indeks terakhir dengan terus menambahkan nilai pada indeks sebelumnya yang tidak mewakili karakter kode kebenaran algoritma Taboo Codes. Ketika setiap pembaca string bit sudah menemukan kode kebenaran algoritma Taboo Codes maka nilai biner tersebut sudah mewakili nilai kebenaran algoritma Taboo

\begin{tabular}{|c|c|c|c|}
\hline Indeks & $\begin{array}{l}\text { Nilai } \\
\text { Biner }\end{array}$ & Keterangan & $\begin{array}{c}\text { Nilai } \\
\text { Heksadesimal }\end{array}$ \\
\hline 1 & 0 & Tidak Ada & \\
\hline 2 & 01 & Tidak Ada & \\
\hline 3 & 010 & Tidak Ada & \\
\hline 4 & 0100 & Ada & 01 \\
\hline 5 & 1 & Tidak Ada & \\
\hline 6 & 11 & Tidak Ada & \\
\hline 7 & 110 & Tidak Ada & \\
\hline 8 & 1100 & Ada & $\mathrm{BD}$ \\
\hline 9 & 1 & Tidak Ada & \\
\hline 10 & 10 & Tidak Ada & \\
\hline 11 & 100 & Tidak Ada & \\
\hline 12 & 1000 & Ada & 00 \\
\hline 13 & 0 & Tidak Ada & \\
\hline 14 & 01 & Tidak Ada & \\
\hline 15 & 010 & Tidak Ada & \\
\hline 16 & 0100 & Ada & 01 \\
\hline 17 & 0 & Tidak Ada & \\
\hline 18 & 01 & Tidak ada & \\
\hline 19 & 010 & Tidak Ada & \\
\hline 20 & 0101 & Tidak Ada & \\
\hline 21 & 01010 & Tidak Ada & \\
\hline 22 & 010101 & Ada & $6 \mathrm{D}$ \\
\hline 23 & 1 & Tidak Ada & \\
\hline 24 & 10 & Tidak Ada & \\
\hline 25 & 100 & Tidak Ada & \\
\hline 26 & 0100 & Ada & 01 \\
\hline 27 & 0 & Tidak Ada & \\
\hline 28 & 01 & Tidakada & \\
\hline 29 & 011 & Tidak Ada & \\
\hline 30 & 0110 & Tidak Ada & \\
\hline 31 & 01100 & Tidak Ada & \\
\hline 32 & 011000 & Ada & 43 \\
\hline 33 & 1 & Tidak Ada & \\
\hline
\end{tabular}
Codes.

Tabel 8. Pengecekan Bit Dekompresi 


\begin{tabular}{|l|l|c|c|}
\hline 34 & 10 & Tidak Ada & \\
\hline 35 & 100 & Tidak Ada & \\
\hline 36 & 1000 & Ada & 01 \\
\hline 37 & 0 & Tidak Ada & \\
\hline 38 & 01 & Tidak Ada & \\
\hline 39 & 010 & Tidak Ada & \\
\hline 40 & 0100 & Ada & 01 \\
\hline 41 & 0 & Tidak Ada & \\
\hline 42 & 01 & Tidak Ada & \\
\hline 43 & 011 & Tidak Ada & \\
\hline 44 & 0111 & Tidak Ada & \\
\hline 45 & 01110 & Tidak Ada & \\
\hline 46 & 011100 & Ada & 55 \\
\hline
\end{tabular}

\section{KESIMPULAN}

Berdasarkan penelitian yang dilakukan pada kompresi file video menggunakan algoritma taboo code maka dapat diambil kesimpula dimana hasil dari kompresi dari sampel data yang digunakan dengan parameter analisis kompresi compression ratio dan space saving dengan hasil compression ratio sebesar 58,33\% dan hasil space saving sebesar $0.1467 \%$ menunjukan tingkat hasil kompresi yang sangat baik pada file video dan sangant baik apabila diterapkan

\section{REFERENCES}

[1] U. S. Utara, U. S. Utara, and U. S. Utara, "Pengamanan File Teks Menggunakan Algoritma Skipjack dan Kompresi Algoritma Taboo," 2018.

[2] R. Syahputra, “KOMPRESI FILE VIDEO MP4 DENGAN MENGGUNAKAN METODE,” pp. 52-57, 2016.

[3] H. T. Sihotang, "PERANCANGAN DAN IMPLEMENTASI ALGORITMA ARITHMETIC CODING UNTUK APLIKASI KOMPRESI DATA VIDEO DAN AUDIO,” vol. 2, no. 1, pp. 58-64, 2018.

[4] D. S. T. Mizwar, G. L. Ginting, Mesran, A. Fau, S. Aripin, “"Implementasi Algoritma J-Bit Encoding pada kompresi File Teks,'KOMIK(Konferensi Nas.Teknol.Inf dan komputer),” vol. 1, pp. 232-236, 2017.

[5] T. Chandra, "Aplikasi Kompresi File dengan Algoritma Elias Gamma," no. 18.

[6] K. Y. and Y. Melita, "Aplikasi kompresi Citra digital menggunakan teknik Kompresi jpeg Dengan fungsi GUI pada Matlab," vol. 3, no. no.2, pp. 269-278, 2011.

[7] D. Salomon and G. Motta, Handbook Of Data Compression, Fifth Edit. London: Springer, 2010.

[8] R.Syahputra, “KOMPRESI FILE VIDEO MP4,” pp. 57-59, 2016.

[9] T. Sutabri, Analisis Sistem Informasi. 2012.

[10] R. A.S-M.Salahuddin, Rekayasa Perangkat Lunak Terstruktur dan Berorientasi Objek, 4th ed. Bandung: Informatika Bandung, 2016.

[11] R. Priyanto, "Langsung Bisa Visual Basic NET 2008," 2010.

[12] M. Sadeli, 7 Jam Belajar Interaktif Visual Basic.net 2008 Untuk Orang Awam. Palembang: Maxikom, 2009. 